\title{
Efficacy and safety of dupilumab for the treatment of uncontrolled asthma: a meta- analysis of randomized clinical trials
}

\author{
Xiao-feng Xiong, Min Zhu, Hong-xia Wu, Li-li Fan and De-yun Cheng
}

\begin{abstract}
Background: Several recent clinical trials have assessed the effects of dupilumab in uncontrolled asthma, but reached no definite conclusion. We therefore conducted this meta-analysis to evaluate the overall efficacy and safety of dupilumab for the treatment of uncontrolled asthma.

Methods: All randomized controlled trials were included. Standard mean differences (SMD) or relative risks (RR) were calculated using Fixed-or random-effects models.

Results: Five studies involving 3369 patients were identified. Pooled analysis showed significant improvements in the first-second forced expiratory volume $\left(F E V_{1}\right)(S M D=4.29,95 \% \mathrm{Cl}: 2.78-5.81)$ and Asthma Quality of Life Questionnaire scores (SMD $=4.39,95 \% \mathrm{Cl}:$ 1.44-7.34). Dupilumab treatments were also associated with significantly decreased 5-item Asthma Control Questionnaire scores ( $\mathrm{SMD}=-4.95,95 \% \mathrm{Cl}:-7.30$ to -2.60$)$, AM and PM asthma symptom scores (SMD $=-5.09,95 \% \mathrm{Cl}:-6.40$ to -3.77 ; $\mathrm{SMD}=-4.92,95 \% \mathrm{Cl}:-5.98$ to -3.86 , respectively), and severe exacerbation risk ( $\mathrm{RR}=0.73 ; 95 \% \mathrm{Cl}: 0.67-0.79)$ compared with placebo, with similar incidence of adverse events (RR $=1.0 ; 95 \% \mathrm{Cl}: 0.96-1.04)$.
\end{abstract}

Conclusion: Dupilumab treatment is relatively well-tolerated and could significantly improve $\mathrm{FEV}_{1}$, symptoms, asthma control, and quality of life, and reduced severe exacerbation risk in patients with uncontrolled asthma.

Keywords: Dupilumab, Meta-analysis, Randomized control trial, Uncontrolled asthma

\section{Introduction}

Asthma is one of the most common chronic diseases and affects around 334 million people worldwide [1], of whom approximately $20-25 \%$ have uncontrolled disease [2]. Many of these patients have substantially reduced lung function and a higher risk of disease exacerbation, despite maximum treatment, and require the use of a considerable proportion of health care resources [3, 4]. Immunologically, type 2 cytokines (specifically interleukin [IL]-4, IL-5, and IL-13) are recognized as playing a substantial pathobiological role in asthma [5-7]. These cytokines link to a type-2/ T-helper-2-cell (Th2)-high molecular asthma phenotype in up to $50 \%$ of asthmatic patients, across all levels of severity [8-10].

Dupilumab, a fully human monoclonal antibody, is directed against the alpha subunit of the IL-4 receptor, thereby blocking both IL-4 and IL-13 signaling, and hence type 2 inflammation [11]. It has been approved for the treatment of moderate-to-severe atopic dermatitis [12]. Several randomized, placebo-controlled studies (RCTs) have shown efficacy of dupilumab in patients with uncontrolled asthma. However, because the sample sizes of these studies were varied and results were less consistent, the evidence is insufficient for drawing robust conclusions. Therefore, we conducted a meta-analysis to assess the overall efficacy and safety of dupilumab treatment for uncontrolled asthma.

* Correspondence: chengdeyunscu@163.com

Department of Respiratory and Critical Care Medicine, West China Hospital,

Sichuan University, NO. 37 Guoxue Alley, Chengdu 610041, Sichuan, China

(c) The Author(s). 2019 Open Access This article is distributed under the terms of the Creative Commons Attribution 4.0 International License (http://creativecommons.org/licenses/by/4.0/), which permits unrestricted use, distribution, and reproduction in any medium, provided you give appropriate credit to the original author(s) and the source, provide a link to the Creative Commons license, and indicate if changes were made. The Creative Commons Public Domain Dedication waiver (http://creativecommons.org/publicdomain/zero/1.0/) applies to the data made available in this article, unless otherwise stated. 


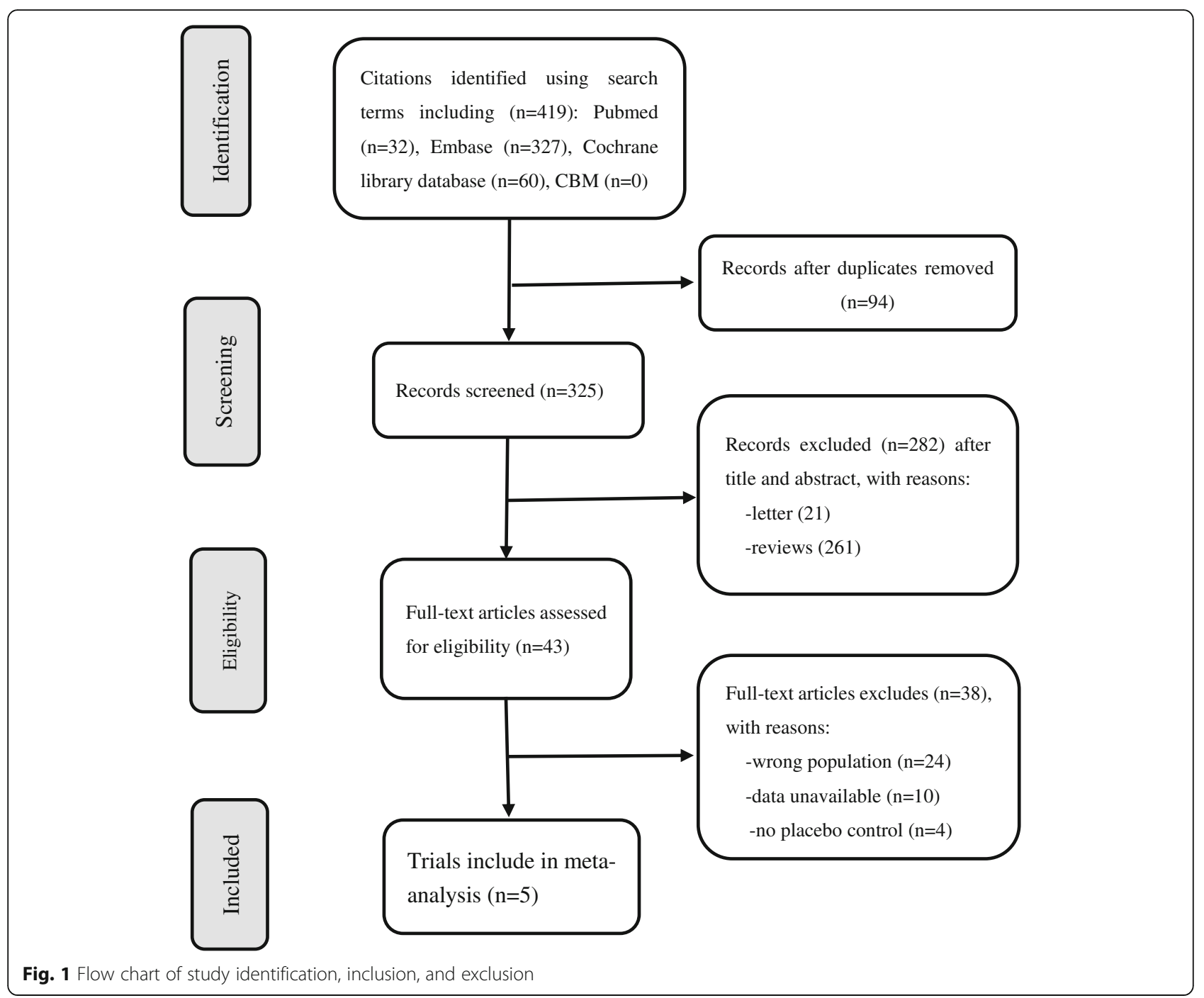

\section{Methods}

\section{Data sources and searches}

We searched PubMed, Embase, the Cochrane Library and Chinese Biological Medicine (CBM) databases for articles published up to June 30,2018 , to identify all trials assessing dupilumab therapy for patients with uncontrolled asthma, using the search terms: "asthma" and "dupilumab". Publication species was limited to humans. In addition, relevant review articles and their reference lists were checked manually.

\section{Study selection}

Studies were considered eligible if they met the following criteria: 1) trials recruited adults/adolescents ( $\geq 12$ years old) diagnosed with uncontrolled asthma, 2) participants received dupilumab therapy at any dose, 3) RCTs, and 4) RCTs reporting the following outcomes: lung function $\left(\mathrm{FEV}_{1}\right)$, he 5-item Asthma
Control Questionnaire (ACQ-5) score, fractional exhaled nitric oxide $\left(\mathrm{FE}_{\mathrm{NO}}\right), \mathrm{AM}$ and $\mathrm{PM}$ asthma symptom scores, quality of life (AQLQ), severe exacerbation rate, or adverse events. Two investigators (XFX and MZ) independently screened all references according to the selection criteria. Disagreements were resolved through discussion.

The patients were diagnosed with asthma persisting for 1 year or more, according to the Global Initiative for Asthma 2009 or 2014 guidelines [13, 14]. Uncontrolled asthma was defined based on current treatment with a medium-to-high-dose inhaled glucocorticoid (fluticasone propionate at a total daily dose of $\geq 500 \mu \mathrm{g}$ or equipotent equivalent), plus up to 2 additional controllers (e.g., a long-acting $\beta 2$-agonist or leukotriene receptor antagonist); a forced expiratory volume in $1 \mathrm{~s}\left(\mathrm{FEV}_{1}\right) \leq 80 \%$ of the predicted normal value before bronchodilator use (or $\leq 90 \%$ of the 
Table 1 Characteristic of randomized controlled trials included

\begin{tabular}{|c|c|c|c|c|c|c|c|c|}
\hline Reference & phase & Country & Asthma severity & $\begin{array}{l}\text { Patients(n) } \\
\text { dupilumab/placebo }\end{array}$ & $\begin{array}{l}\text { Treatment } \\
\text { duration }\end{array}$ & $\begin{array}{l}\text { Follow } \\
\text { up }\end{array}$ & Dosage & Outcomes \\
\hline $\begin{array}{l}\text { Wenzel } \\
2013[27]\end{array}$ & $2 \mathrm{~A}$ & The US & 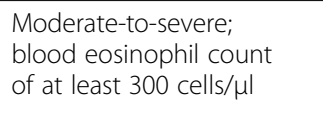 & $52 / 52$ & 12 weeks & $\begin{array}{l}8 \\
\text { weeks }\end{array}$ & $\begin{array}{l}300 \mathrm{mg} \\
\mathrm{q} 1 \mathrm{w}\end{array}$ & $\begin{array}{l}\mathrm{FEV}_{1} ; \mathrm{PEF} ; \mathrm{ACQ} 5 \text { score; } \mathrm{FE}_{\mathrm{NO}} ; \\
\text { Asthma exacerbations; } \\
\text { Morning and evening } \\
\text { asthma score }\end{array}$ \\
\hline $\begin{array}{l}\text { Wenzel } \\
2016[15]\end{array}$ & $2 b$ & Multinational & $\begin{array}{l}\text { Uncontrolled moderate-to- } \\
\text { severe asthma }\end{array}$ & $611 / 158$ & 24 weeks & $\begin{array}{l}12 \\
\text { weeks }\end{array}$ & $\begin{array}{l}200 \mathrm{mg} \\
\mathrm{q} 4 \mathrm{w} \\
300 \mathrm{mg} \\
\mathrm{q} 4 \mathrm{w} \\
200 \mathrm{mg} \\
\mathrm{q} 2 \mathrm{w} \\
300 \mathrm{mg} \\
\mathrm{q} 2 \mathrm{w}\end{array}$ & $\begin{array}{l}\mathrm{FEV}_{1} \text {; } \mathrm{ACQ} 5 \text { score; } \mathrm{FE}_{\mathrm{NO}} \text {; } \mathrm{AQLQ} ; \\
\text { Severe asthma exacerbations; } \\
\text { Morning and evening asthma } \\
\text { score }\end{array}$ \\
\hline $\begin{array}{l}\text { Castro } \\
2018[26]\end{array}$ & 3 & Multinational & $\begin{array}{l}\text { Uncontrolled } \\
\text { moderate-to-severe } \\
\text { asthma }\end{array}$ & $\begin{array}{l}\text { Group 1: } 631 / 313 \\
\text { Group 2: 632/321 }\end{array}$ & 52 weeks & $\begin{array}{l}12 \\
\text { weeks }\end{array}$ & $\begin{array}{l}200 \mathrm{mg} \\
\mathrm{q} 2 \mathrm{w} \\
300 \mathrm{mg} \\
\mathrm{q} 2 \mathrm{w}\end{array}$ & $\begin{array}{l}\mathrm{FEV}_{1} ; \mathrm{PEF} \text {; ACQ5 score; } \mathrm{FE}_{\mathrm{NO}} \text {; } \\
\text { AQLQ; Severe asthma } \\
\text { exacerba-tions; } \\
\text { Morning and evening } \\
\text { asthma score }\end{array}$ \\
\hline $\begin{array}{l}\text { Rabe } \\
2018 \text { [25] }\end{array}$ & 3 & Multinational & $\begin{array}{l}\text { Oral glucocorticoid- } \\
\text { dependent severe } \\
\text { asthma }\end{array}$ & 103/107 & 24 weeks & NM & $\begin{array}{l}300 \mathrm{mg} \\
\mathrm{q} 2 \mathrm{w}\end{array}$ & $\begin{array}{l}\mathrm{FEV}_{1} ; \mathrm{FE}_{\mathrm{NO}} ; \\
\text { Severe asthma exacerbations } \\
\text { Reduction in the oral } \\
\text { glucocorticoid dose }\end{array}$ \\
\hline $\begin{array}{l}\text { Weinstein } \\
2018 \text { [24] }\end{array}$ & $2 b$ & Multinational & $\begin{array}{l}\text { Uncontrolled } \\
\text { persistent asthma }\end{array}$ & $\begin{array}{l}\text { Group 1: 92/56 } \\
\text { Group 2: } 157 / 84\end{array}$ & 24 weeks & NM & $\begin{array}{l}200 \mathrm{mg} \\
\mathrm{q} 2 \mathrm{w} \\
300 \mathrm{mg} \\
\mathrm{q} 2 \mathrm{w}\end{array}$ & $\begin{array}{l}\mathrm{FEV}_{1} ; \\
\text { Severe asthma exacerbations }\end{array}$ \\
\hline
\end{tabular}

Abbreviations: $F E V_{1}$ forced expiratory volume in $1 \mathrm{~s}, P E F$ peak expiratory flow, $A C Q-5$ 5-item Asthma Control Questionnaire, $F E_{N O}$ fractional exhaled nitric oxide, $A Q L Q$ the Asthma Quality of Life Questionnaire, NM not mentioned, $q 1 w$ once weekly, $q 2 w$ every 2 weeks, $q 4 w$ every 4 weeks

predicted normal value in those $12-17$ years of age); $\mathrm{FEV}_{1}$ reversibility of at least $12 \%$ and $200 \mathrm{ml}$ [15]; the 5-item Asthma Control Questionnaire (ACQ-5) score $\geq 1.5$ (on a scale from 0 [no impairment] to 6 [maximum impairment]; the minimal clinically important difference is 0.5) [16]; and a worsening of asthma in the previous year that led to hospitalization, emergency medical care, or treatment with systemic glucocorticoids $\geq 3$ days [15]. Asthma symptom scores are patient-reported measures of asthma symptoms, taken upon waking and in the evening. Their effects on activities (PM) and sleep (AM) were noted. These symptom scores range from 0 to 4, with higher scores indicating greater disruption [15]. A severe exacerbation was defined as a deterioration of asthma that required the use of systemic corticosteroids for at least 3 days, or hospital admission, or an emergency department visit because of asthma, treated with systemic corticosteroids [17]. The AQLQ is a patient-reported measure of the effect of asthma on quality of life; higher scores indicate a better quality of life; a global score is calculated and ranges from 0 to 7 [15].

\section{Data extraction and quality assessment}

The Preferred Reporting Items for Systemic Reviews and Meta-Analyses (PRISMA) statement was followed. Two authors (XFX and MZ) performed data extracted and recorded desirable information of each enrolled study in a standard form as recommended by Cochrane [18]. Any disagreement was resolved through discussion or adjudicated by a third author (HXW). In addition, we evaluated the risk of bias using the Cochrane Collaboration's domains [19].

\section{Statistical analyses}

Intervention effects were presented using risk ratios (RR) and 95\% confidence intervals (CIs) for dichotomous data and using mean differences (MD) and 95\% CIs for continuous data. If a trial presented more than 2 intervention groups, we combined 2 or 3 groups into a single group according to the Cochrane handbook [19]. Heterogeneity was quantified by $\mathrm{I}^{2}$ statistic and the $\mathrm{X}^{2}$ test. Random-effects model was performed in the presence of high heterogeneity $\left(\mathrm{I}^{2}>50 \%\right)$; otherwise, fixed-effects model was applied [20]. Meta-regression was used to explore potential sources of heterogeneity. Funnel plots with the Begg's and Egger's tests were used to test publication bias [21]. All statistical analysis was accomplished by an independent statistician using Review Manager (Version 5.3, The Cochrane Collaboration, Copenhagen) and Stata (Version 12.0, Stata 


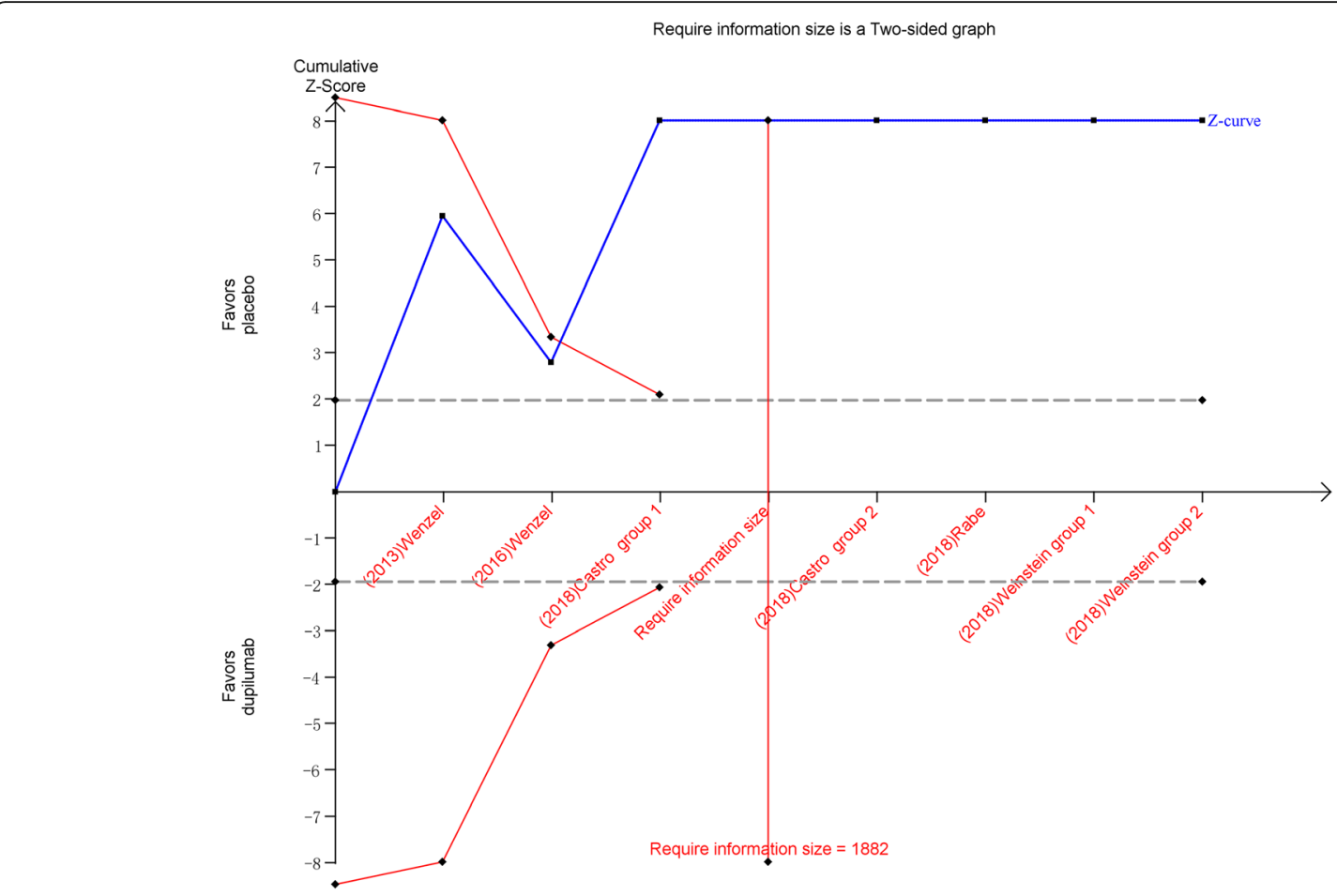

Fig. 2 Trial sequential analysis of 5 trials comparing dupilumab with placebo for $\mathrm{FEV}_{1}$. Trial sequential analysis of 7 groups (two trial contains two groups) illustrating that the cumulative z curve crossed both the conventional boundary and the trial sequential monitoring boundary, establishing sufficient and conclusive evidence and suggesting that further trials are not required. Using $a=0.05$ (two-sided) and $\beta=0.20$ (power of $80 \%$ ) calculate that the optimal sample size was 1882 patients

Corporation, USA), and rendered statistical significance as $P$-value $<0.05$.

Meta-analyses may cause type I errors because of sparse data and repetitive testing of accumulating data [22]. We performed trial sequential analysis (TSA) to assess the risk of type I errors, which can identify whether the evidence in a meta-analysis is reliable and authentic. If the cumulative $\mathrm{z}$ curve crosses the trial, the boundaries, and the required information size, the evidence is sufficient to reach a conclusion, and no further studies are needed. We calculated the required information size for $\mathrm{FEV}_{1}$ using $\alpha=0.05$ (2-sided) and $\beta=0.20$ (power of $80 \%$ ). TSA version 0.9 beta (http://www.ctu.dk/tsa) was applied for the analyses [23].

\section{Results}

\section{Study identification}

The initial database search resulted in 419 articles. After reviewing the titles and abstracts, 43 were found to be relevant for further detailed evaluation. Of these 38 were excluded as the population was wrong $(n=24)$, there

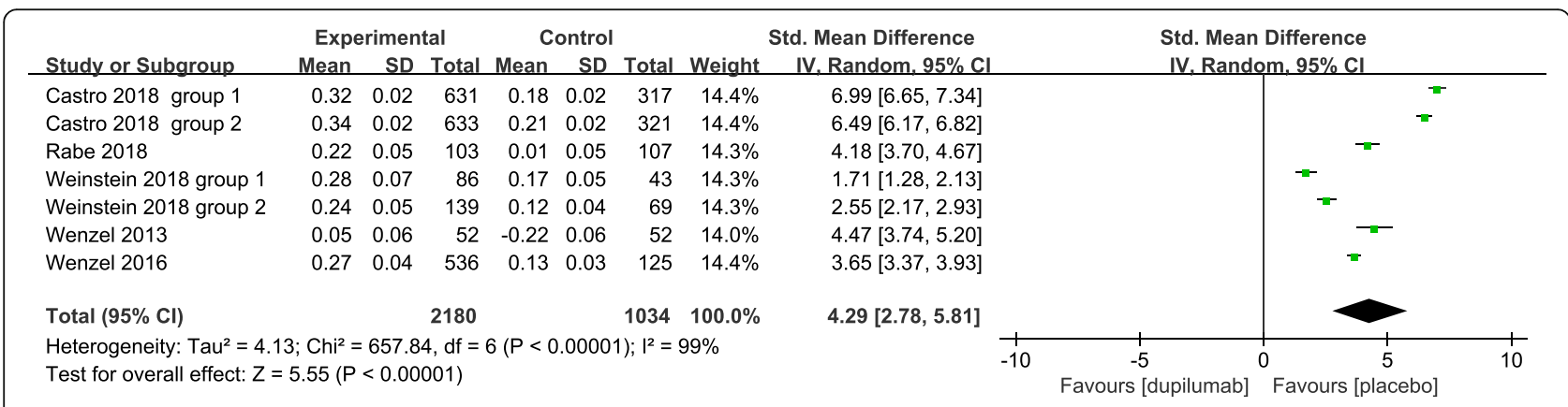

Fig. 3 The effect of dupilumab versus placebo on $\mathrm{FEV}_{1}$. SD = standard derivation, IV = Inverse Variance, $\mathrm{Cl}=$ confidence interval, Std. Mean Difference $=$ standardized mean difference 


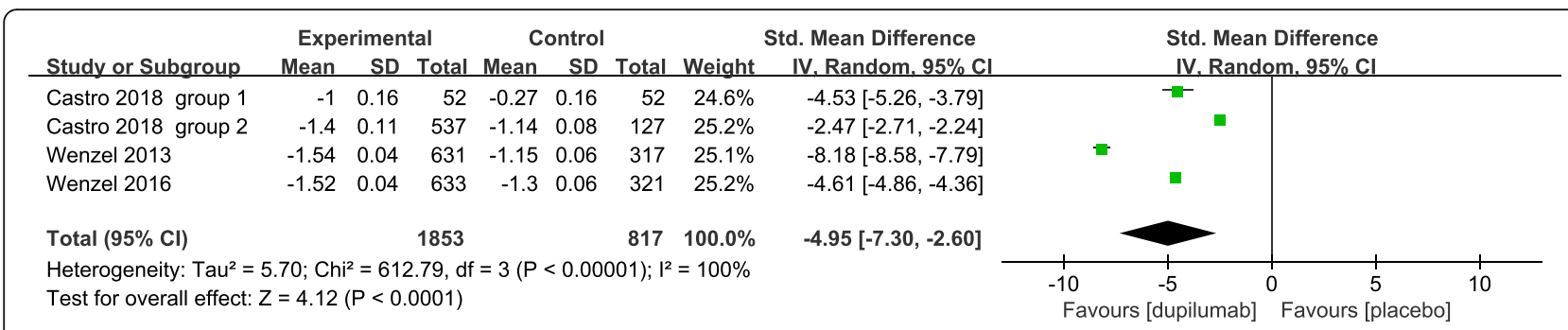

Fig. 4 The effect of dupilumab versus placebo on ACQ-5 score. ACQ-5 =5-item Asthma Control Questionnaire, SD = standard derivation, IV = Inverse Variance, $\mathrm{Cl}=$ confidence interval, Std. Mean Difference = standardized mean difference

was no placebo control $(n=4)$, or data were unavailable $(n=10)$. Thus, 5 RCTs were included in the meta-analysis [15, 24-27] (Fig. 1).

\section{Study characteristics}

We enrolled 5 studies with 3369 patients (Table 1). The sample sizes ranged from 52 to 632 subjects. A single intervention group (dupilumab $300 \mathrm{mg} \mathrm{qw}$ and $300 \mathrm{mg}$ $\mathrm{q} 2 \mathrm{w}$ ) was presented in 2 trials, and the remaining studies included 2 or more interventions (dupilumab $200 \mathrm{mg}$ q2w, $200 \mathrm{mg}$ q4w, $300 \mathrm{mg}$ q2w, $300 \mathrm{mg}$ q4w). Outcome reporting varied among the trials. $\mathrm{FEV}_{1}$ was reported in 5 studies [15, 24-27]. Severe asthma exacerbations rate was reported in 4 trials $[15,24-26]$. ACQ-5 scores, $\mathrm{FE}_{\mathrm{NO}}$, and $\mathrm{AM}$ and $\mathrm{PM}$ asthma symptom scores were reported in 3 trials $[15,26,27]$. AQLQ was reported in 2 trials $[15,26]$.

\section{Trial sequential analysis}

TSA found that the optimal sample size required for reliable detection of a reasonable effect of dupilumab treatment on $\mathrm{FEV}_{1}$ of asthma was 1882 participants; the number of patients included in our study far exceeded this number. TSA presented that the cumulative $\mathrm{z}$ curve crossed both the conventional boundary and the sequential monitoring boundary, which indicated that the cumulative evidence is reliable and authentic. Therefore, further studies were not needed (Fig. 2).

\section{Efficacy}

We assessed severity measures for efficacy including lung function $\left(\mathrm{FEV}_{1}\right), \mathrm{ACQ}-5$ score, $\mathrm{FE}_{\mathrm{NO}}, \mathrm{AM}$ and PM asthma symptom scores, severe asthma exacerbation rate, and quality of life (AQLQ). Overall, our studies illustrated significant improvement in the efficacy in the treatment of asthma with the use of dupilumab in terms of all clinical indexes. The pooled analyses indicated that dupilumab treatment significantly improved $\mathrm{FEV}_{1}(\mathrm{SMD}=4.29,95 \% \mathrm{CI}: 2.78$ to 5.81, $P<0.001)$. However, there was a high level of heterogeneity $\left(\mathrm{I}^{2}=99 \%, P<0.001\right)$ (Fig. 3$)$, with no evidence of publication bias (Egger's test $P=1.00$; Begg's test $P=0.61$ ). In terms of ACQ-5 scores and $\mathrm{FE}_{\mathrm{NO}}$, our meta-analysis showed that dupilumab administration significantly decreased the ACQ-5 score and $\mathrm{FE}_{\mathrm{NO}}(\mathrm{SMD}=-4.95,95 \% \mathrm{CI}:-7.30$ to -2.60 , $P<0.001 ;$ SMD $=-2.40,95 \%$ CI: -3.64 to $-1.17, P<$ 0.001 , respectively), with high heterogeneity $\left(\mathrm{I}^{2}=\right.$ $100 \%, P<0.001$ ) (Figs. 4 and 5 ), but no publication bias (Egger's test $P=0.73$; Begg's test $P=0.52$; Egger's test $P=0.68$; Begg's test $P=0.58$, respectively). Similar efficacy was observed in terms of the AM and PM asthma symptom score. Compared with placebo, dupilumab resulted in a greater reduction in the AM and PM asthma symptom scores $(\mathrm{SMD}=-5.09,95 \%$ $\mathrm{CI}:-6.40$ to $-3.77, P<0.001 ; \mathrm{SMD}=-4.92,95 \% \mathrm{CI}$ : -5.98 to $-3.86, P<0.001$, respectively), with high

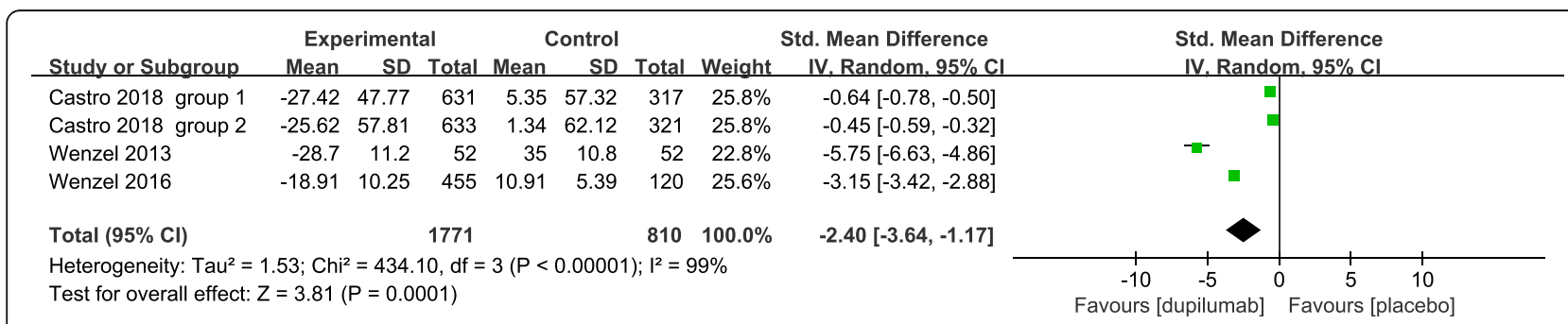

Fig. 5 The effect of dupilumab versus placebo on $\mathrm{FE}_{\mathrm{NO}}$. $\mathrm{FE}_{\mathrm{NO}}=$ fractional exhaled nitric oxide $\mathrm{SD}=\mathrm{standard}$ derivation, $\mathrm{IV}=\mathrm{Inverse} \mathrm{Variance}$, $\mathrm{CI}=$ confidence interval, Std. Mean Difference = standardized mean difference 


\begin{tabular}{|c|c|c|c|c|c|c|c|c|c|c|c|}
\hline \multirow[b]{2}{*}{ Study or Subgroup } & \multicolumn{3}{|c|}{ Experimental } & \multicolumn{2}{|c|}{ Control } & & & \multirow{2}{*}{$\begin{array}{l}\text { Std. Mean Difference } \\
\text { IV. Random, } 95 \% \mathrm{Cl}\end{array}$} & \multicolumn{3}{|c|}{ Std. Mean Difference } \\
\hline & Mean & SD & Total & Mean & SD & Total & Weight & & & om, $95 \% \mathrm{Cl}$ & \\
\hline Castro 2018 group 1 & -0.53 & 0.03 & 631 & -0.33 & 0.04 & 317 & $25.8 \%$ & $-5.93[-6.23,-5.64]$ & 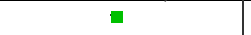 & & \\
\hline Castro 2018 group 2 & -0.51 & 0.03 & 633 & -0.36 & 0.04 & 321 & $25.9 \%$ & $-4.45[-4.69,-4.21]$ & - & & \\
\hline Wenzel 2013 & -0.4 & 0.1 & 52 & 0.3 & 0.1 & 52 & $22.5 \%$ & $-6.95[-7.98,-5.91]$ & - & & \\
\hline Wenzel 2016 & -0.45 & 0.06 & 574 & -0.26 & 0.05 & 143 & $25.9 \%$ & $-3.26[-3.51,-3.01]$ & - & & \\
\hline Total $(95 \% \mathrm{Cl})$ & & & 1890 & & & 833 & $100.0 \%$ & $-5.09[-6.40,-3.77]$ & & & \\
\hline $\begin{array}{l}\text { Heterogeneity: } \mathrm{Tau}^{2}= \\
\text { Test for overall effect: }\end{array}$ & $\begin{array}{l}.72 ; \mathrm{Chi}^{2} \\
=7.59\end{array}$ & $\begin{array}{l}2=203 \\
(P<0 .\end{array}$ & $\begin{array}{l}3.37, \mathrm{df}= \\
00001)\end{array}$ & $=3(P$ & $<0.000$ & $001) ; 1^{2}=$ & $=99 \%$ & & $\begin{array}{ccc}-10 & -5 & 0 \\
\text { Favours [dupilumab] }\end{array}$ & $\begin{array}{cc}0 & 5 \\
\text { Favours [placebo] }\end{array}$ & 10 \\
\hline
\end{tabular}

heterogeneity $\left(\mathrm{I}^{2}=99 \%, P<0.001 ; \mathrm{I}^{2}=98 \%, P<0.001\right.$, respectively) (Figs. 6 and 7), and no publication bias (Egger's test $P=0.73$; Begg's test $P=0.51$ ). Additionally, dupilumab treatment was associated with a significant reduction in severe asthma exacerbation risk ( $\mathrm{RR}=0.73 ; 95 \% \mathrm{CI}: 0.67$ to $0.79 ; P<0.001$ ) (Fig. 8), without heterogeneity among studies $\left(\mathrm{I}^{2}=0 \%, P=\right.$ 0.59), or publication bias (Egger's test $P=0.98$; Begg's test, $P=0.62$ ). For AQLQ, our analysis demonstrated that dupilumab treatment significantly increased AQLQ scores $(\mathrm{SMD}=4.39,95 \% \mathrm{CI}: 1.44$ to $7.34, P=$ $0.004)$, with high heterogeneity $\left(\mathrm{I}^{2}=100 \%, P<0.001\right)$ (Fig. 9), and no publication bias (Egger's test, $P=0.27$; Begg's test, $P=0.07$ ).

\section{Safety}

All studies presented adverse events and dupilumab was relatively tolerated. The overall frequency of adverse events was similar in dupilumab-treated (79.2\%) and placebo-treated (78.6\%) patients $(\mathrm{RR}=1.0 ; 95 \%$ CI: 0.96 to $1.04 ; P=0.94)$, with no heterogeneity $\left(\mathrm{I}^{2}=\right.$ $0 \%, P=0.59$ ) (Fig. 10) and no publication bias (Egger's test $P=1.00$; Begg's test, $P=0.69$ ). The incidence of serious adverse events was relatively low in the dupilumab treatment group (2-8.7\%). Common adverse events were injection-site reactions, upper respiratory tract infection, headache, nasopharyngitis, bronchitis, and sinusitis (Table 2).

\section{Quality of the individual studies and subgroup analyses} All trials had a low risk of bias in terms of the 6 domains (Fig. 11). The publication bias of trials was estimated by visual inspection of the funnel plot and Egger's test, and there was no publication bias (Fig. 12, $P=1.00$ ). According to the funding source, subgroup analyses were performed to assess sponsorship biases. Unfortunately, all studies were funded by a pharmaceutical company (Sanofi or Regeneron Pharmaceuticals). Thus, the results should be expounded with caution. In order to examine the source of heterogeneity, subgroup analyses were conducted for $\mathrm{FEV}_{1}$ and ACQ-5 scores. The studies were stratified in terms of the effects model, region of trial, sample size, treatment duration, blood eosinophil count, and sources of funding, but no significant difference was found between groups in terms of FEV $\mathrm{V}_{1}$ and ACQ-5 scores (Table 3).

\section{Discussion}

To our knowledge, this is the first meta-analysis and comparison of all published data of RCTs on the use of dupilumab for the treatment of uncontrolled asthma. Our study indicated that dupilumab treatment was relatively tolerated and could significantly improve $\mathrm{FEV}_{1}$ and quality of life, and reduced the disease symptom score and severe exacerbations risk in patients with uncontrolled asthma.

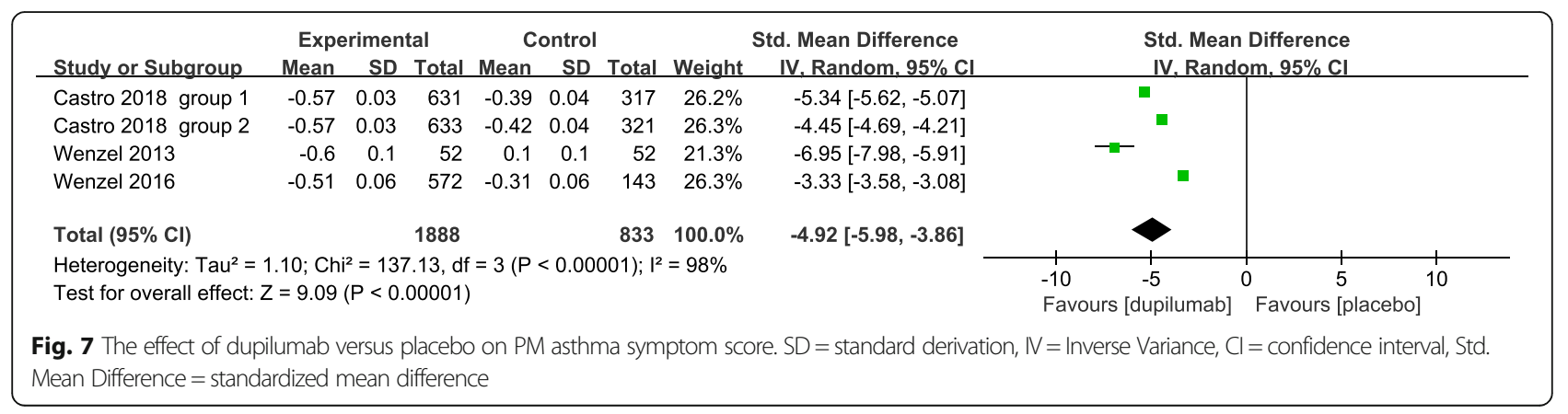




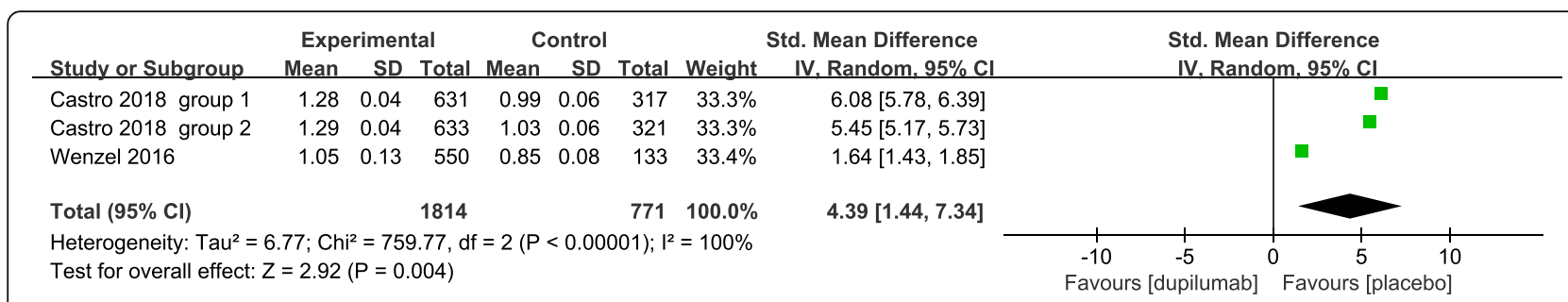

Fig. 8 The effect of dupilumab versus placebo on $A Q L Q$. AQLQ = Asthma Quality of Life Questionnaire, $S D=$ standard derivation, IV = Inverse Variance, $\mathrm{Cl}=$ confidence interval, Std. Mean Difference $=$ standardized mean difference

Asthma is a heterogeneous disease [1]. Previous studies have indicated that the Th2 cytokines IL-4 and IL-13 play a part in asthma $[28,29]$. Dupilumab is an IL-4R antagonist that inhibits the IL-4 and IL-13 signaling pathway. Several clinical trials have been performed evaluating the effect of dupilumab in uncontrolled asthma. However, the evidence was insufficient to allow sound conclusions to be drawn, because the sample sizes varied; therefore, further analyses were necessary.

Based on pooled analyses, we found that dupilumab could significantly improve $\mathrm{FEV}_{1}$ in patients with uncontrolled asthma. The clinical relevance of this finding may be clinically important, suggesting a potential effect of dupilumab on airway remodeling. However, a previous study [24] failed to show a significant effect on lung function as compared with placebo, which may be attributed to the small sample size and unselected population of patients with asthma. Compared to the previous study, we identified a selected population of patients with uncontrolled asthma. Moreover, we performed TSA to estimate the required information size for analysis, which can decrease the risk of random errors. Thus, our results may be more plausible. In addition, the different outcomes between our study and the previous trial suggested that dupilumab may be valid only in a targeted subgroup with uncontrolled asthma.

Three trails $[15,26,27]$ showed that dupilumab could significantly reduce ACQ-5 scores and asthma symptom scores, which was consistent with our findings. AQLQ is a disease-specific health-related quality of life instrument that contains 32 items has been proven to be responsive in before-after studies and in clinical trials [30]. In our study, we used the AQLQ score to assess the quality of life of patients. Dupilumab treatment significantly improved AQLQ score in patients with uncontrolled asthma, this result was consistent with those of previous reviews. However, the mean change in AQLQ was less than the minimally important clinical difference of 0.5 units [31]. Thus, the relation of this finding to patients may not be clinically significant.

Given that nitric oxide (NO)-synthase activity and NO production are promoted by $\mathrm{IL}-13, \mathrm{FE}_{\mathrm{NO}}$ levels can be used as a biomarker of Th2 inflammation and of IL-13

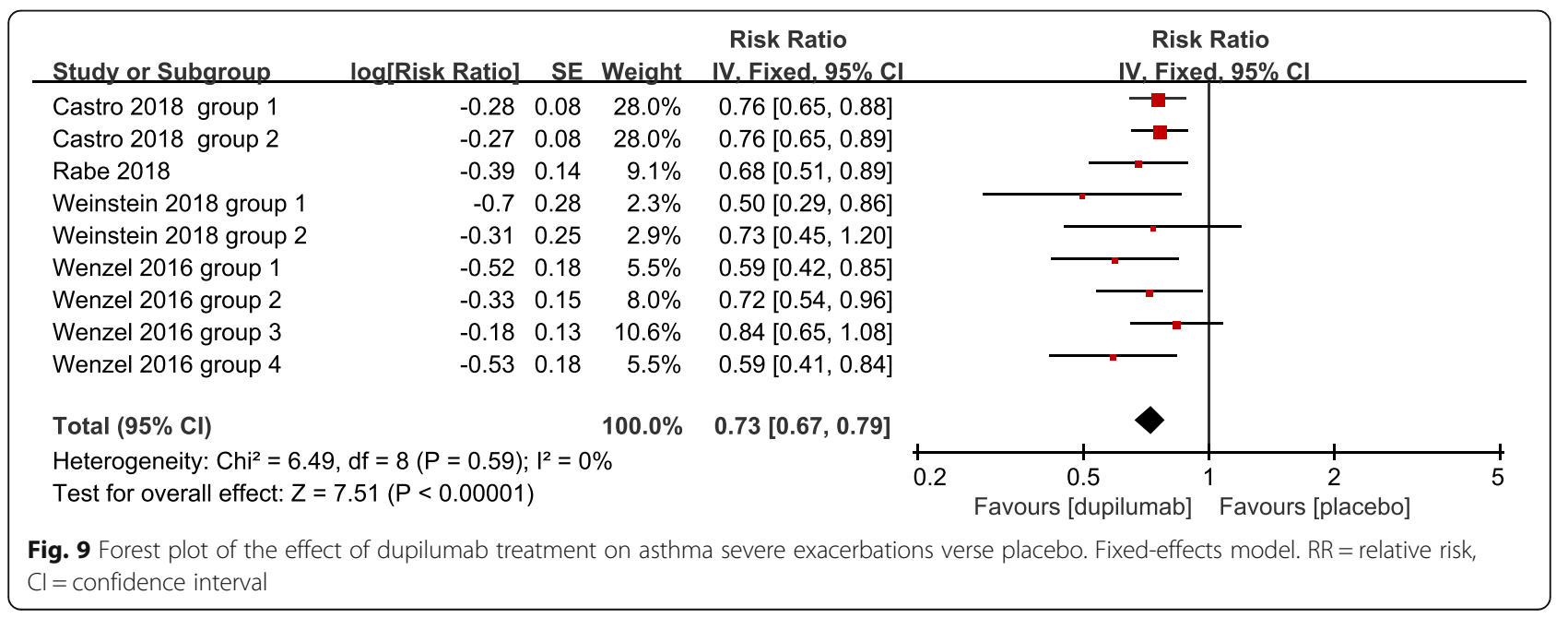




\begin{tabular}{|c|c|c|c|c|c|c|c|c|c|}
\hline Study or Subgroup & $\begin{array}{l}\text { dupilum } \\
\text { Events }\end{array}$ & $\begin{array}{l}\text { nab } \\
\text { Total }\end{array}$ & $\begin{array}{l}\text { placeb } \\
\text { Events }\end{array}$ & Total & Weight & $\begin{array}{l}\text { Risk Ratio } \\
\mathrm{M}-\mathrm{H}, \text { Fixed, } 95 \% \mathrm{Cl}\end{array}$ & $\begin{array}{r}\text { Risk } \\
\text { M-H, Fixe } \\
\end{array}$ & $\begin{array}{l}\text { Ratio } \\
\text { d. } 95 \% \mathrm{Cl}\end{array}$ & \\
\hline Castro 2018 group 1 & 508 & 631 & 257 & 313 & $30.4 \%$ & $0.98[0.92,1.05]$ & & & \\
\hline Castro 2018 group 2 & 515 & 632 & 270 & 321 & $31.7 \%$ & $0.97[0.91,1.03]$ & $\rightarrow$ & & \\
\hline Rabe 2018 & 64 & 103 & 69 & 107 & $6.0 \%$ & $0.96[0.78,1.18]$ & & & \\
\hline Weinstein 2018 group 1 & 71 & 95 & 42 & 56 & $4.7 \%$ & $1.00[0.82,1.21]$ & & & \\
\hline Weinstein 2018 group 2 & 124 & 157 & 60 & 84 & $6.9 \%$ & $1.11[0.94,1.29]$ & & & \\
\hline Wenzel 2013 & 40 & 52 & 42 & 52 & $3.7 \%$ & $0.95[0.78,1.16]$ & & & \\
\hline Wenzel 2016 & 483 & 611 & 118 & 158 & $16.6 \%$ & $1.06[0.96,1.17]$ & & & \\
\hline Total $(95 \% \mathrm{Cl})$ & & 2281 & & 1091 & $100.0 \%$ & $1.00[0.96,1.04]$ & & & \\
\hline Total events & 1805 & & 858 & & & & & & \\
\hline $\begin{array}{l}\text { Heterogeneity: } \mathrm{Chi}^{2}=4.4 \\
\text { Test for overall effect: } Z=\end{array}$ & $\begin{array}{l}\mathrm{df}=6(P \\
0.15(P=\end{array}$ & $\begin{array}{l}=0.61) \\
0.88)\end{array}$ & $;\left.\right|^{2}=0 \%$ & & & & $\begin{array}{lc}0.5 & 0.7 \\
& \text { Favours [dupilumab] }\end{array}$ & $\begin{array}{c}1.5 \\
\text { Favours [placebo] }\end{array}$ & 2 \\
\hline
\end{tabular}

levels in the bronchial mucosa [32]. Therefore, $\mathrm{FE}_{\mathrm{NO}}$ levels could decrease after treatment with anti-IL-4/13 therapy [33]. The current meta-analysis further confirmed this theory: our study showed a significantly decrease in $\mathrm{FE}_{\mathrm{NO}}$ levels after dupilumab treatment. Similarly, all previous trials of dupilumab treating uncontrolled asthma observed a reduction in the $\mathrm{FE}_{\mathrm{NO}}$

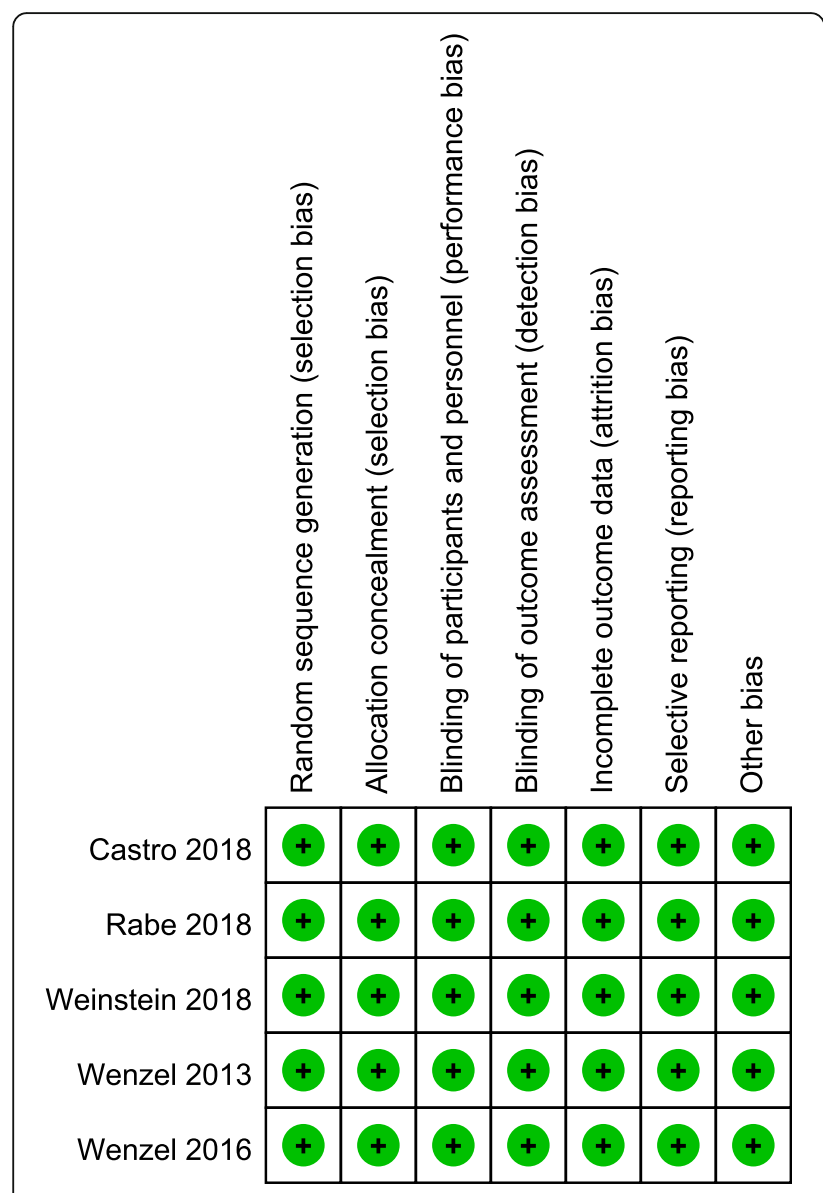

Fig. 11 Risk of bias summary of included studies summary level, which is consistent with the mechanism of action of dupilumab.

Severe asthma exacerbations are related to substantial mortality [34]. Reducing asthma exacerbation risk is a key target of disease management. The part of Th2 inflammation is about $50 \%$ of asthmatic patients, in whom proinflammatory cytokines abnormally product, such as IL-4, IL-5, and IL-13, which induce IgE synthesis and eosinophilic inflammation [35]. Trials using specific inhibitors have indicated a relation between eosinophils and the pathogenesis of asthma exacerbations [36, 37]. Therefore, it is hypothesized that anti-IL-4 and anti-IL-13 therapies could decrease asthma exacerbation by inhibiting eosinophilic and airway inflammation. In further sustain of this concept, our study showed a significant reduction in severe exacerbation rates with dupilumab treatment. The improvements in asthma-related quality of life with dupilumab treatment may contribute to preventing severe asthma exacerbations.

The whole safety profile of dupilumab was equivalent to that of placebo in all RCTs, and the common adverse events were injection-site reactions, upper respiratory tract infection, headache, nasopharyngitis, bronchitis, and sinusitis. Four trials [15, 25-27] showed that the rates of upper respiratory tract infection in the dupilumab-treated group were low and similar to placebo group. However, all RCTs included revealed that the incidence of injection-site reactions was slightly higher in the dupilumab regimens. Therefore, more data are required to support the safety profile of dupilumab in terms of injection-site reactions.

This meta-analysis has some shortcomings. First, the severity of uncontrolled asthma and baseline therapy varied among studies; thus, it is impossible to probe the impact of these factors on results. Second, significant heterogeneity existed among trials evaluating FEV1, ACQ-5 score, $\mathrm{FE}_{\mathrm{NO}}$, and $\mathrm{AQLQ}$, possible 
Table 2 Summary of adverse events in dupilumab treatment arm

\begin{tabular}{llllll}
\hline Event & Wenzel 2013 [27] & Wenzel 2016 [15] & Castro 2018 [26] & Rabe 2018 [25] & Weinstein 2018 [24] \\
\hline Any adverse event & $42(80.8)$ & $483(79.1)$ & $1023(81.0)$ & $64(62.1)$ & $195(78.3)$ \\
Serious adverse event & $1(2.0)$ & $45(7.4)$ & $104(8.2)$ & $9(8.7)$ & $15(6.0)$ \\
Any adverse event leading to death & $\mathrm{NM}$ & $2(<0.1)$ & $5(0.4)$ & 0 & 0 \\
$\begin{array}{l}\text { Study discontinuation owing to treatment-emergent } \\
\text { adverse event }\end{array}$ & $3(5.8)$ & $27(4.4)$ & $63(5.0)$ & $1(1.0)$ & $8(3.0)$ \\
Most common adverse events & & & & & \\
Injection-site reactions & $15(28.8)$ & $79(12.9)$ & $212(16.8)$ & $9(8.7)$ & $60(24.1)$ \\
Upper respiratory tract infection & $7(13.5)$ & $216(35.4)$ & $146(11.6)$ & NM & NM \\
Viral upper respiratory tract infection & $3(5.8)$ & $83(13.6)$ & $230(18.2)$ & $9(8.7)$ & NM \\
Headache & $6(11.5)$ & $62(10.1)$ & $86(6.8)$ & NM & NM \\
Nasopharyngitis & $7(13.5)$ & $59(9.7)$ & NM & NM & NM \\
Bronchitis & NM & $51(8.3)$ & $144(11.4)$ & $7(6.8)$ & NM \\
Sinusitis & $1(2.0)$ & $36(5.9)$ & $62(4.9)$ & $7(6.8)$ & NM \\
\hline
\end{tabular}

Note: Data are $\mathrm{n}(\%)$

Abbreviations: NM not mentioned

sources of heterogeneity might include different geographic regions and races. Third, we combined 2 or 3 intervention groups into a single group according to the Cochrane handbook, regardless of differences in intervention dosage, which made it hard to determine the optimal dose. Last, as all the RCTs involved the pharmaceutical industry, the positive outcomes should be expounded cautiously. Our study also had some strengths; for instance, our patient selection was highly consistent, and all trials were of high quality, such that the internal validity of our meta-analysis was high.

\section{Conclusions}

The current meta-analysis demonstrated that dupilumab treatment was relatively tolerated and significantly improved $\mathrm{FEV}_{1}$, symptoms, asthma control, and quality of life, and reduced severe exacerbation risk in patients with uncontrolled asthma. Thus, dupilumab may be effective and safe for the treatment of uncontrolled

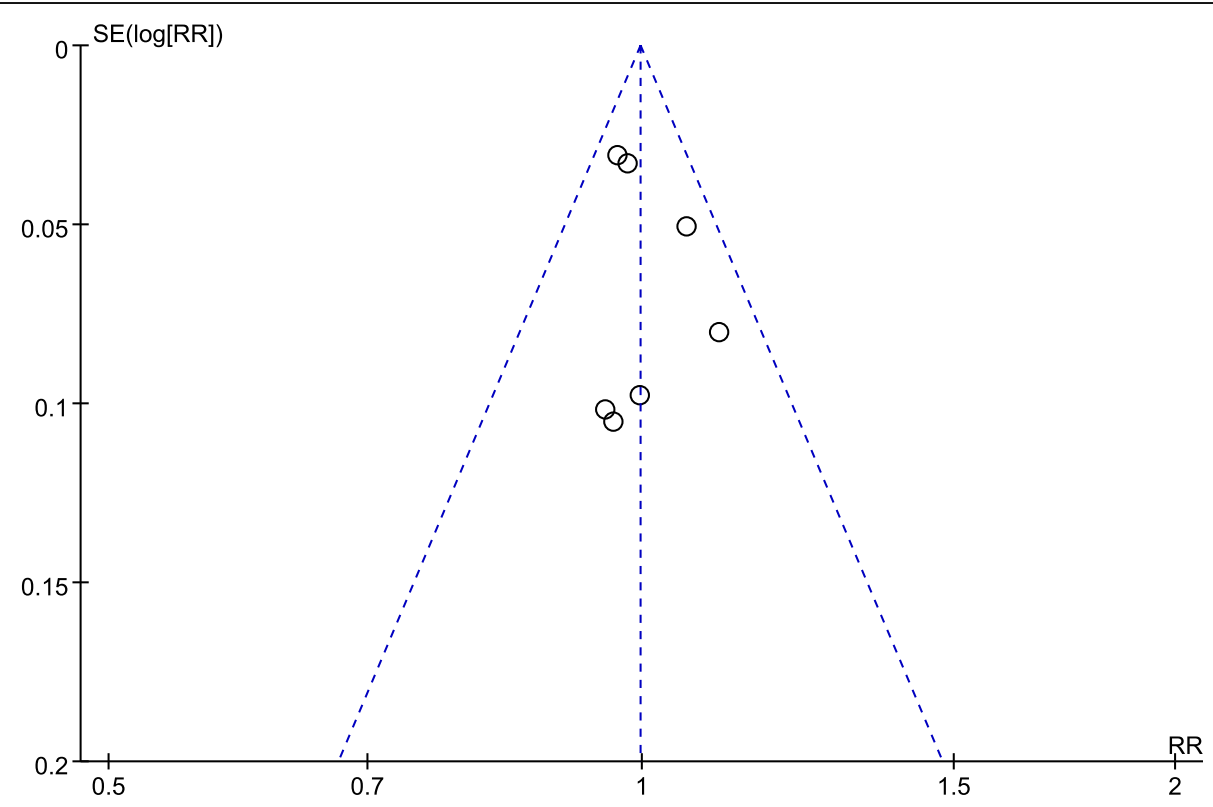

Fig. 12 Funnel plot of the included studies evaluated adverse events 
Table 3 Subgroup analysis and sensitivity analyses of FEV $_{1}$ and ACQ-5 scores in RCTs

\begin{tabular}{|c|c|c|c|c|c|c|c|c|}
\hline \multirow[t]{2}{*}{ Stratification Subgroup analysis } & \multicolumn{4}{|l|}{$\mathrm{FEV}_{1}$} & \multicolumn{4}{|l|}{ ACQ-5 scores } \\
\hline & $\begin{array}{l}\text { No. of Patients } \\
\text { (trials) }\end{array}$ & $\begin{array}{l}\text { SMD } \\
(95 \% \mathrm{Cl})\end{array}$ & $P$ Value & $\mathrm{I}_{2}, \%$ & $\begin{array}{l}\text { No. of Patients } \\
\text { (trials) }\end{array}$ & $\begin{array}{l}\text { SMD } \\
(95 \% \mathrm{Cl})\end{array}$ & $P$ Value & $I_{2}, \%$ \\
\hline \multicolumn{9}{|l|}{ Effects model } \\
\hline Random-effects model & $3218(7)$ & 4.29 (2.78 to 5.81$)$ & $<0.001$ & 99 & $2670(4)$ & $-4.95(-7.30$ to -2.60$)$ & $<0.001$ & 100 \\
\hline Fixed effects model & $3218(7)$ & 4.48 (4.32 to 4.62$)$ & $<0.001$ & 99 & $2670(4)$ & $-4.24(-4.40$ to -4.09$)$ & $<0.001$ & 100 \\
\hline \multicolumn{9}{|l|}{ Region of study } \\
\hline The US & $104(1)$ & 4.47 (3.74 to 5.20$)$ & $<0.001$ & - & $104(1)$ & $-4.53(-5.26$ to -3.79$)$ & $<0.001$ & - \\
\hline Multinational & $3114(6)$ & 4.31 (2.85 to 5.97$)$ & $<0.001$ & 99 & $2566(3)$ & $-5.09(-7.29$ to -2.25$)$ & $<0.001$ & 100 \\
\hline \multicolumn{9}{|l|}{ No. of subjects } \\
\hline$<150$ & $651(4)$ & 3.21 (1.98 to 4.43$)$ & $<0.001$ & 96 & $104(1)$ & $-4.53(-5.26$ to -3.79$)$ & $<0.001$ & - \\
\hline$\geq 150$ & $2567(3)$ & 5.80 (3.86 to 7.74$)$ & $<0.001$ & 99 & $2566(3)$ & $-5.09(-7.29$ to -2.25$)$ & $<0.001$ & 100 \\
\hline \multicolumn{9}{|l|}{ Treatment duration } \\
\hline$<50$ weeks & $1316(4)$ & 3.35 (2.36 to 4.34$)$ & $<0.001$ & 96 & $768(2)$ & $-3.47(-5.48$ to -1.46$)$ & $<0.001$ & 96 \\
\hline$\geq 50$ weeks & $1902(2)$ & 6.74 (6.25 to 7.23$)$ & $<0.001$ & 77 & $1902(2)$ & $-6.39(-9.89$ to -2.89$)$ & $<0.001$ & 100 \\
\hline \multicolumn{9}{|l|}{ Blood eosinophil count } \\
\hline$<300$ eosinophils per $\mu \mathrm{l}$ & $1536(5)$ & 5.56 (2.59 to 8.53$)$ & $<0.001$ & 99 & $388(1)$ & $-1.80(-2.08$ to -1.52$)$ & $<0.001$ & - \\
\hline$\geq 300$ eosinophils per $\mu \mathrm{l}$ & $1269(4)$ & 2.05 (0.97 to 3.12 ) & $<0.001$ & 98 & $380(2)$ & $-2.43(-6.52$ to -1.66$)$ & $<0.001$ & 99 \\
\hline \multicolumn{9}{|l|}{ Sources of funding } \\
\hline Pharmaceutical company & & 4.29 (2.78 to 5.81$)$ & $<0.001$ & 99 & & $-4.95(-7.30$ to -2.60$)$ & $<0.001$ & 100 \\
\hline Non-pharmaceutical company & $0(0)$ & - & - & - & - & - & - & - \\
\hline
\end{tabular}

Abbreviations: FEV1 forced expiratory volume in $1 \mathrm{~s}, A C Q-5$ 5-item Asthma Control Questionnaire

asthma. These results highlight the significance of selecting the population patient of asthma that could obtain clinical benefit from dupilumab. Injection-site reaction was the most frequently reported adverse event in all studies involving dupilumab treatment. Further long-term trials are required to determine the optimum dose of dupilumab for asthma.

\section{Abbreviations}

ACQ-5: 5-item Asthma Control Questionnaire; AQLQ: The Asthma Quality of Life Questionnaire; $\mathrm{FE}_{\mathrm{NO}}$ : Fractional exhaled nitric oxide; $\mathrm{FEV}_{1}$ : Forced expiratory volume in $1 \mathrm{~s}$; IgE: Immunoglobulin E; IL: Interleukin; NM: Not mentioned; NO: Nitric oxide; PEF: Peak expiratory flow; q1w: Once weekly; q2w: Every 2 weeks; q4w: Every 4 weeks; RCTs: Randomized, placebocontrolled studies; RR: Relative risk; SMD: Standard mean differences; Th2: Thelper-2-cell

\section{Acknowledgments}

We are grateful to the authors of the primary studies included in this metaanalysis.

\section{Funding}

This study did not receive any funding.

\section{Authors' contributions}

X-FX and MZ performed the literature searches, selected the studies, analyzed the data and wrote the manuscript draft. H-XW and L-LF aided in the data analysis. DYC designed the study and revised manuscript.

All authors read and approved the final manuscript.

Ethics approval and consent to participate

For this type of study formal consent is not required.
Consent for publication

Not applicable.

\section{Competing interests}

The authors declare that they have no competing interest.

\section{Publisher's Note}

Springer Nature remains neutral with regard to jurisdictional claims in published maps and institutional affiliations.

Received: 12 October 2018 Accepted: 6 May 2019

Published online: 31 May 2019

\section{References}

1. Disease GBD, Injury I, Prevalence C. Global, regional, and national incidence, prevalence, and years lived with disability for 328 diseases and injuries for 195 countries, 1990-2016: a systematic analysis for the global burden of Disease study 2016. Lancet. 2017; 390:1211-59.

2. Peters SP, Ferguson G, Deniz Y, Reisner C. Uncontrolled asthma: a review of the prevalence, disease burden and options for treatment. Respir Med. 2006;100:1139-51.

3. Kerkhof M, Tran TN, Soriano JB, Golam S, Gibson D, Hillyer EV, Price DB. Healthcare resource use and costs of severe, uncontrolled eosinophilic asthma in the UK general population. Thorax. 2018;73:116-24.

4. Lange P, Parner J, Vestbo J, Schnohr P, Jensen G. A 15-year follow-up study of ventilatory function in adults with asthma. N Engl J Med. 1998;339:1194-200.

5. Chung KF, Wenzel SE, Brozek JL, Bush A, Castro M, Sterk PJ, Adcock IM, Bateman ED, Bel EH, Bleecker ER, et al. International ERS/ATS guidelines on definition, evaluation and treatment of severe asthma. Eur Respir J. 2014;43: 343-73.

6. Wenzel S, Wilbraham D, Fuller R, Getz EB, Longphre M. Effect of an interleukin-4 variant on late phase asthmatic response to allergen 
challenge in asthmatic patients: results of two phase 2a studies. Lancet. 2007;370:1422-31.

7. Locksley RM. Asthma and allergic inflammation. Cell. 2010;140:777-83.

8. Woodruff PG, Modrek B, Choy DF, Jia G, Abbas AR, Ellwanger A, Koth $L L$, Arron JR, Fahy JV. T-helper type 2-driven inflammation defines major subphenotypes of asthma. Am J Respir Crit Care Med. 2009: 180:388-95

9. Corren J, Lemanske RF, Hanania NA, Korenblat PE, Parsey MV, Arron JR, Harris JM, Scheerens H, Wu LC, Su Z, et al. Lebrikizumab treatment in adults with asthma. N Engl J Med. 2011;365:1088-98.

10. Chung KF. Targeting the interleukin pathway in the treatment of asthma. Lancet. 2015;386:1086-96.

11. Gandhi NA, Pirozzi G, Graham NMH. Commonality of the IL-4/IL-13 pathway in atopic diseases. Expert Rev Clin Immunol. 2017;13:425-37.

12. Shirley M. Dupilumab: First Global Approval. Drugs. 2017;77:1115-21.

13. Global Initiative for Asthma (GINA). 2009 Global strategy for asthma management and prevention. https://ginasthma.org/. Accessed 22 June 2018.

14. Global Initiative for Asthma (GINA). 2015 Global strategy for asthma management and prevention. https://ginasthma.org/wp-content/uploads/ 2016/01/GINA_Report. Accessed 22 June 2018.

15. Wenzel S, Castro M, Corren J, Maspero J, Wang L, Zhang B, Pirozzi G, Sutherland ER, Evans RR, Joish VN, et al. Dupilumab efficacy and safety in adults with uncontrolled persistent asthma despite use of medium-to-highdose inhaled corticosteroids plus a long-acting beta $<$ inf $>2</$ inf $>$ agonist: a randomised double-blind placebo-controlled pivotal phase $2 \mathrm{~b}$ dose-ranging trial. Lancet. 2016;388:31-44.

16. Juniper EF, Svensson K, Mork AC, Stahl E. Measurement properties and interpretation of three shortened versions of the asthma control questionnaire. Respir Med. 2005;99:553-8.

17. Busse WW, Maspero JF, Rabe KF, Papi A, Wenzel SE, Ford LB, Pavord ID, Zhang B, Staudinger H, Pirozzi G, et al. Liberty asthma QUEST: phase 3 randomized, double-blind, placebo-controlled, parallel-group study to evaluate Dupilumab efficacy/safety in patients with uncontrolled, moderateto-severe asthma. Adv Ther. 2018:35:737-48.

18. Moher D, Liberati A, Tetzlaff J, Altman DG, Group P. Preferred reporting items for systematic reviews and meta-analyses: the PRISMA statement. J Clin Epidemiol. 2009;62:1006-12.

19. Higgins J. Green S. Cochrane handbook for systematic reviews of interventions version 5.1. 0. The Cochrane Collaboration, 2011. 2013.

20. Higgins JP, Thompson SG. Quantifying heterogeneity in a meta-analysis. Stat Med. 2002;21:1539-58.

21. Egger M, Davey Smith $G$, Schneider M, Minder C. Bias in meta-analysis detected by a simple, graphical test. BMJ. 1997;315:629-34.

22. Brok J, Thorlund K, Wetterslev J, Gluud C. Apparently conclusive metaanalyses may be inconclusive-trial sequential analysis adjustment of random error risk due to repetitive testing of accumulating data in apparently conclusive neonatal meta-analyses. Int J Epidemiol. 2009:38:28798.

23. Thorlund K, Engstrøm J, Wetterslev J, Brok J, Imberger G, Gluud C. User manual for trial sequential analysis (TSA). Copenhagen: Copenhagen Trial Unit, Centre for Clinical Intervention Research; 2011.

24. Weinstein SF, Katial R, Jayawardena S, Pirozzi G, Staudinger H, Eckert L, Joish VN, Amin N, Maroni J, Rowe P, et al. Efficacy and safety of dupilumab in perennial allergic rhinitis and comorbid asthma. J Allergy Clin Immunol. 2018;142(1):171-177.e1.

25. Rabe KF, Nair P, Brusselle G, Maspero JF, Castro M, Sher L, Zhu H, Hamilton JD, Swanson BN, Khan A, et al. Efficacy and safety of Dupilumab in glucocorticoid-dependent severe asthma. N Engl J Med. 2018;378:2475-85.

26. Castro M, Corren J, Pavord ID, Maspero J, Wenzel S, Rabe KF, Busse WW, Ford L, Sher L, FitzGerald JM, et al. Dupilumab efficacy and safety in moderate-to-severe uncontrolled asthma. N Engl J Med. 2018;378:2486-96.

27. Wenzel S, Ford L, Pearlman D, Spector S, Sher L, Skobieranda F, Wang L, Kirkesseli $S$, Rocklin $R$, Bock B, et al. Dupilumab in persistent asthma with elevated eosinophil levels. New England J Med. 2013;368:2455-66.

28. Kay AB. The role of T lymphocytes in asthma. Chem Immunol Allergy. 2006; 91:59-75.

29. Gandhi NA, Bennett BL, Graham NM, Pirozzi G, Stahl N, Yancopoulos GD. Targeting key proximal drivers of type 2 inflammation in disease. Nat Rev Drug Discov. 2016;15:35-50.
30. Juniper EF, Guyatt G, Epstein R, Ferrie P, Jaeschke R, Hiller TK. Evaluation of impairment of health related quality of life in asthma: development of a questionnaire for use in clinical trials. Thorax. 1992;47:76-83.

31. Juniper EF, Guyatt GH, Willan A, Griffith LE. Determining a minimal important change in a disease-specific quality of life questionnaire. I Clin Epidemiol. 1994;47:81-7.

32. Barranco P, Phillips-Angles E, Dominguez-Ortega J, Quirce S. Dupilumab in the management of moderate-to-severe asthma: the data so far. Ther Clin Risk Manag. 2017;13:1139-49.

33. Chibana K, Trudeau JB, Mustovich AT, Hu H, Zhao J, Balzar S, Chu HW, Wenzel SE. IL-13 induced increases in nitrite levels are primarily driven by increases in inducible nitric oxide synthase as compared with effects on arginases in human primary bronchial epithelial cells. Clin Exp Allergy. 2008; 38:936-46.

34. Masoli M, Fabian D, Holt S, Beasley R, Global initiative for asthma P. The global burden of asthma: executive summary of the GINA dissemination committee report. Allergy. 2004;59:469-78.

35. Bagnasco D, Ferrando M, Varricchi G, Passalacqua G, Canonica GW. A critical evaluation of anti-IL-13 and anti-IL-4 strategies in severe asthma. Int Arch Allergy Immunol. 2016;170:122-31.

36. Green RH, Brightling CE, McKenna S, Hargadon B, Parker D, Bradding P, Wardlaw AJ, Pavord ID. Asthma exacerbations and sputum eosinophil counts: a randomised controlled trial. Lancet. 2002;360:1715-21.

37. Nadif R, Siroux V, Oryszczyn MP, Ravault C, Pison C, Pin I, Kauffmann F, Epidemiological study on the $\mathrm{G}$, environment of $\mathrm{A}$. Heterogeneity of asthma according to blood inflammatory patterns. Thorax. 2009;64:374-80.

\section{Ready to submit your research? Choose BMC and benefit from:}

- fast, convenient online submission

- thorough peer review by experienced researchers in your field

- rapid publication on acceptance

- support for research data, including large and complex data types

- gold Open Access which fosters wider collaboration and increased citations

- maximum visibility for your research: over $100 \mathrm{M}$ website views per year

At BMC, research is always in progress.

Learn more biomedcentral.com/submissions 